1.はじめに
○小椎一
（日立照明株式会社）

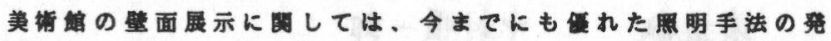
表がいろいろあり、又、展示用スポットライトについても器明理 哈の立がされている。

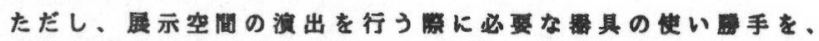

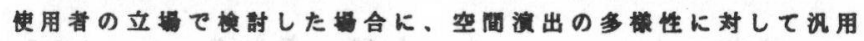
形のスポットライトでは機啿的に不夼分な点があったが、今回、 使用者サイドの意見をもとに、桧画展示用としてほほ湍足で事る

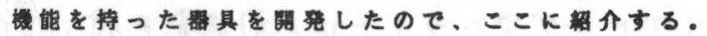

\title{
2. 譽具内客について
}

展示空間の演出を主体とするレフランプ品用形と、䑪画の見え 方を重视したハロゲンランプ使用形を、展示内容によって使い分 けるものとし、展示室の籍高と器具取付位雷より、各稳サイスの 桧画に堼虑できる機能を持たせている。(图一1，图－2）

ーハロゲンスポットライトの特長 -

A. 2 段伸船アルミオーハルパイプとワンタッチクリップて高 さ需艒が赛易にでる。

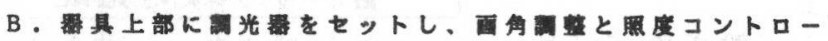
ルを同時灣作でをる。

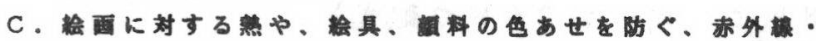

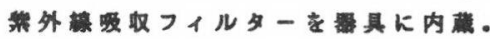

D．眼射面の均伖度、特にランプによる光ムラを防ぐために特 策胡エを施したランプの使用。

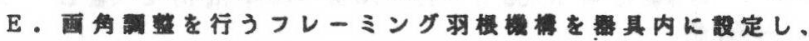
桧画中心の照射面搷作が行なえる。

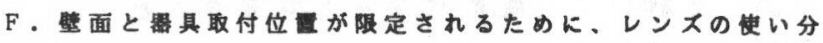
けで狭照形と広缺形を用意し、桧画サイスによって速定す る。

レフランプスポットライトも A ・ B C C の特長を持ち、2 稳類 の器具と、展示室のベース照明の䍀光とを粗み合わせることで、 展示空間の演出が客易となった。(图ー3)

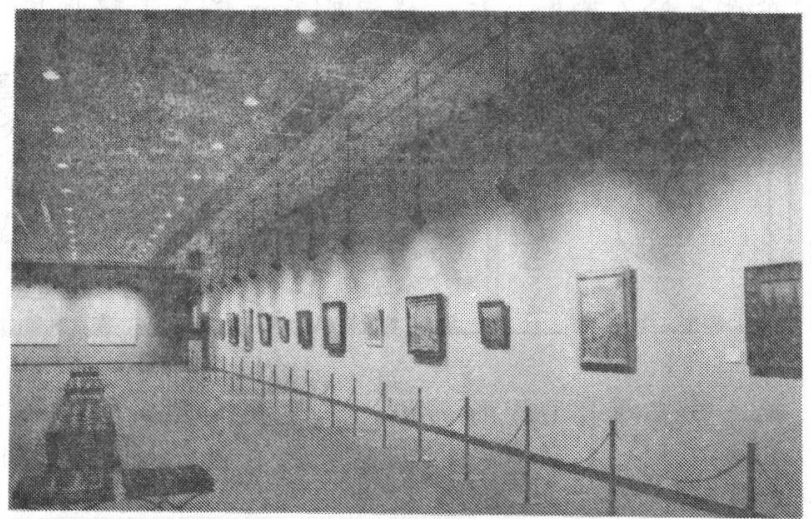

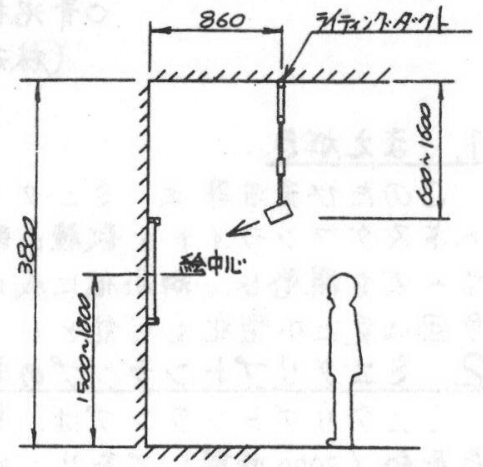

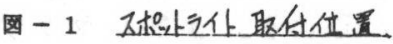

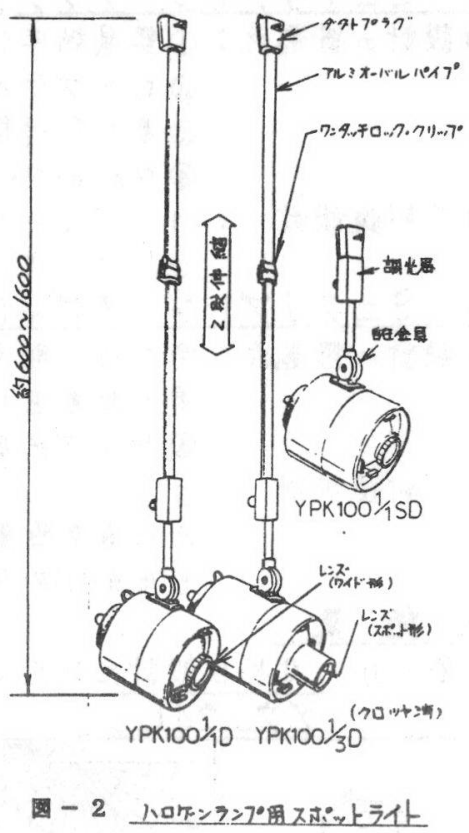

図一 3 . 展示室 